EDITOR'S
CHOICE

\title{
Hepatic progenitor cells from adult human livers for cell transplantation
}

\author{
T S Weiss, ${ }^{1,2}$ M Lichtenauer, ${ }^{1,2}$ S Kirchner, ${ }^{1,2}$ P Stock, ${ }^{3}$ H Aurich, ${ }^{3}$ B Christ, ${ }^{3}$ \\ G Brockhoff, ${ }^{4}$ L A Kunz-Schughart, ${ }^{4}$ K-W Jauch, ${ }^{5}$ H-J Schlitt, ${ }^{1,2}$ W E Thasler ${ }^{5}$
}

${ }^{1}$ Department of Surgery, University of Regensburg Hospital, Germany; ${ }^{2}$ Center for Liver Cell Research, University of Regensburg Hospital, Germany;

${ }^{3}$ Department of Internal

Medicine, Martin Luther

University of Halle-Wittenberg,

Germany; ${ }^{4}$ Department of

Pathology, University of

Regensburg, Germany;

${ }^{5}$ Department of Surgery, LM

University Munich, Hospital

Grosshadern, Germany

\section{Correspondence to:}

Dr Thomas S Weiss, Center for Liver Cell Research, University of Regensburg Hospital, F.-J.-S.-

Allee 11, 93053 Regensburg,

Germany; thomas.weiss@

klinik.uni-regensburg.de

LAK-S is now at OncoRay -

Center for Radiation Research in Oncology, Medical Faculty Carl

Gustav Carus, Dresden

University of Technology,

Fetscherstr. 74, 01307 Dresden,

Germany.

Revised 7 March 2008

Accepted 9 April 2008

Published Online First

16 April 2008

\begin{abstract}
Objective: Liver regeneration is mainly based on cellular self-renewal including progenitor cells. Efforts have been made to harness this potential for cell transplantation, but shortage of hepatocytes and premature differentiated progenitor cells from extra-hepatic organs are limiting factors. Histological studies implied that resident cells in adult liver can proliferate, have bipotential character and may be a suitable source for cell transplantation.

Methods: Particular cell populations were isolated after adequate tissue dissociation. Single cell suspensions were purified by Thy-1 positivity selection, characterised in vitro and transplanted in immunodeficient Pfp/Rag2 mice.
\end{abstract}

Results: Thy $-1^{+}$cells that are mainly found in the portal tract and the surrounding parenchyma, were isolated from surgical liver tissue with high yields from specimens with histological signs of regeneration. Thy $-1^{+}$cell populations were positive for progenitor (CD34, c-kit, CK14, M2PK, OV6), biliary (CK19) and hepatic (HepPar1) markers revealing their progenitor as well as hepatic and biliary nature. The potential of Thy $-1^{+}$cells for differentiation in vitro was demonstrated by increased mRNA and protein expression for hepatic (CK18, HepPar1) and biliary (CK7) markers during culture while progenitor markers CK14, chromogranin $\mathrm{A}$ and nestin were reduced. After transplantation of Thy- $1^{+}$cells into livers of immunodeficient mice, engraftment was predominantly seen in the periportal portion of the liver lobule. Analysis of in situ material revealed that transplanted cells express human hepatic markers HepPar1 and albumin, indicating functional engraftment.

Conclusion: Bipotential progenitor cells from human adult livers can be isolated using Thy- 1 and might be a potential candidate for cell treatment in liver diseases.

In response to liver injury, hepatic cells, especially hepatocytes, can rapidly proliferate to repair liver damage. ${ }^{1}$ After hepatectomy hepatocytes are able to undergo numerous cell divisions maintaining their fully differentiated state to compensate for hepatocyte loss, whereas undifferentiated liver progenitor cells play only a minor role in this process. Interestingly, under conditions such as some chronic liver diseases and after acute necrosis these hepatocyte progenitors play an important role, in particular when growth response of mature hepatocytes is impaired. ${ }^{12}$

Mechanisms leading to progenitor cell activation have been studied in detail using rodent models of hepatocarcinogenesis and liver regeneration after toxic injury. ${ }^{3} 4$ Under these conditions increasing numbers of small cells $(\sim 10 \mu \mathrm{m})$ were observed having a large nuclear-to-cytoplasm ratio with an oval-shaped nucleus (oval cells). They express markers of both hepatocyte lineages and the biliary epithelium that includes bile ducts as well as the canal of Hering. ${ }^{6}$ Although histochemical studies suggest that epithelial cells residing within the canal of Hering might be resident liver stem cells, the precise origin remains ambiguous. ${ }^{6}$ In humans these cells are termed progenitor cells/ductular reaction ${ }^{7}$ and are activated in different diseases such as chronic viral hepatitis, alcoholic liver disease, nonalcoholic fatty liver disease and cirrhosis. ${ }^{4} 8$ They are observed in the portal region of the hepatic lobule $e^{9-11}$ and, furthermore, their numbers increase in direct proportion to disease severity. ${ }^{12}$

Hepatic progenitor cells have also been shown to express haematopoietic stem cell (HSC) markers CD34, c-kit (CD117) ${ }^{13}$ and Thy-1 (CD90). ${ }^{14}$ Accordingly, it was hypothesised that these cells are haematopoietic stem cells transdifferentiated into the hepatic lineage. ${ }^{15}$ However, recent reports have demonstrated that cell fusion rather than transdifferentiation is involved in this process. Also, it was shown that rodent oval cells do not originate from bone marrow, ${ }^{16}$ but bone-marrowderived stem cells may contribute to liver regeneration in an as yet unknown mechanism. ${ }^{17}$

Isolation procedures for hepatic progenitor cells were established for rodents and in vitro studies have shown that these cells are capable of differentiating into hepatocytes and bile duct cells under appropriate conditions. ${ }^{18}$ Isolation of liver progenitor cells from human material has proven more difficult. Indeed, only a few reports describe an isolation of progenitor cells from fetal livers. These cells expressed various lineage specific antigens including biliary and hepatocellular markers. ${ }^{19}$ In adult human liver, progenitor cells have been identified by CD34 and c-kit immunoreactivity, ${ }^{13}$ but the so-called sidepopulation was also found. ${ }^{20}$ Recently, it was documented that Thy-1 (CD90) is expressed in human hepatoblastoma. ${ }^{21}$ This surface antigen has also been useful for successfully isolating progenitor cells from human fetal liver. ${ }^{14}$ However, to our knowledge, there have been no attempts so far to use this marker for the separation of progenitor cell populations from adult human liver tissues. Since such cell populations may become central determinants for future treatments of liver diseases requiring clinically relevant liver regeneration, we aimed to identify and isolate Thy- $1^{+}$cells from adult liver tissue for cell transplantation purposes. We analysed the phenotypic characteristics of Thy- $1^{+}$human progenitor cells after isolation, studied their differentiation potential in vitro and monitored their repopulation capacity in vivo in a mouse model of liver regeneration. 
Table 1 Antibodies used for immunohistochemistry (IHC) and flow cytometry

\begin{tabular}{llllll}
\hline Antibody & Species & Manufacturer & Catalogue number & Dilution & Application \\
\hline Albumin & Rabbit polyclonal IgG & Abcam & ab2406 & $1: 1000$ & IHC \\
CD3-FITC & Mouse monoclonal IgG2a/MEM-57 & AbD Serotec & MCA2184F & $5 \mu l / 10^{6}$ cells & Flow cytometry \\
CD14-FITC & Mouse monoclonal IgG1/MEM-18 & AbD Serotec & MCA2185F & $5 \mu / / 10^{6}$ cells & Flow cytometry \\
CD34 & Mouse monoclonal IgG1/0bend10 & Dako & M7165 & $1: 100$ & IHC \\
CD34-FITC & Mouse monoclonal IgG1/8G12 & BD & 345801 & $20 \mu / / 10^{6}$ cells & Flow cytometry \\
CD45-FITC & Mouse monoclonal IgG1/2D1 & BD & 345808 & $10 \mu l / 10^{6}$ cells & Flow cytometry \\
Thy-1 (CD90) & Mouse monoclonal IgG1/5E10 & BD Pharmingen & 555593 & $1: 250$ & IHC, Flow cytometry \\
CD90-PE & Mouse monoclonal IgG1/5E10 & BD Pharmingen & 555596 & $5 \mu / / 10^{6}$ cells & Flow cytometry \\
C-kit (CD117) & Mouse monoclonal IgG2a/K45 & NeoMarkers & MS-289 & $1: 100$ & IHC \\
CD117-PE & Mouse monoclonal IgG1/104D2 & Southern Biotech & $9815-09 C$ & $10 \mu l / 10^{6}$ cells & Flow cytometry \\
CK7 & Mouse monoclonal IgG & Dako & M7018 & $1: 100$ & IHC \\
CK14 & Rabbit polyclonal IgG & Zytomed & RP113 & $1: 50$ & IHC \\
CK18 & Mouse monoclonal IgG1/CK2 & Chemicon & MAB3404 & $1: 100$ & IHC \\
CK19 & Mouse monoclonal IgG1/RCK108 & Dako & M0888 & $1: 100$ & IHC \\
HepPar1 & Mouse monoclonal IgG1/OCH1E5 & Dako & M7158 & $1: 50$ & IHC \\
M2-PK & Mouse monoclonal IgG1/DF4 & ScheBo Biotech & S-1 & $1: 10$ & IHC \\
OV6 & Mouse & Gift from S. Sell & & $1: 100$ & IHC
\end{tabular}

Manufacturers: Abcam, Cambridge, UK; AbD Serotec, Düsseldorf, Germany; BD, Heidelberg, Germany; BD Pharmingen, Heidelberg, Germany; Chemicon, Schwalbach, Germany; NeoMarkers, Dreieich, Germany; ScheBo Biotech, Giessen, Germany; Southern Biotech, Birmingham, Alabama, USA; Zytomed, Berlin, Germany.

${ }^{*}$ We are grateful to Dr S. Sell (Department of Pathology and Laboratory Medicine, Albany, NY, USA) for the kind gift of OV6 antibody.

\section{MATERIALS AND METHODS Reagents and material}

Antibodies for this study are summarised in table 1. Mouse antirabbit IgG, rabbit anti-mouse IgG, and mouse APAAP were obtained from Dako (Hamburg, Germany). Texas red-conjugated donkey anti-rabbit antibody and fluorescein isothiocyanate (FITC)-conjugated donkey anti-mouse antibody were obtained from Jackson Immunoresearch (Newmarket, UK). RNase A was purchased from Qiagen (Hilden, Germany), DNase I and fast red substrate from Roche Diagnostics (Mannheim, Germany). All further chemicals were purchased from Sigma (Taufkirchen, Germany) or Merck (Darmstadt, Germany).

Tissue samples from human liver resections were obtained from patients undergoing partial hepatectomy. Experimental procedures were performed according to the guidelines of the charitable state-controlled foundation HTCR (Human Tissue and Cell Research), with the informed patient's consent approved by the local ethics committee of the University of Regensburg. ${ }^{22}$ A total of 39 liver specimens were categorised into regenerating ( $\mathrm{n}=20$; age 53.7 (SD 15.6) years; male 13, female 7) and non-regenerating ( $n=19$; age 61.7 (SD 12.2) years; male 15, female 4) tissue according to a histological and clinical examination by specialist. Non-regenerating liver was assigned to patients with metastatic liver tumours of colorectal cancer and regenerating liver to patients with disease as following: fibrosis/cirrhosis ( $n=4$; age 53.0 (SD 9.3) years; male 4), fibrosis/non-alcoholic steatohepatitis (NASH) ( $\mathrm{n}=4$; age 58.0 (SD 11.2) years; male 2, female 2), fibrosis/alcoholic steatohepatitis $(\mathrm{ASH})(\mathrm{n}=1$; age 23 ; female), cirrhosis/ASH $(\mathrm{n}=2$; age 64.5 (SD 4.5) years; male 2), steatosis ( $\mathrm{n}=7$; age 53.7 (SD 19.7) years; male 3 , female 4$)$, ASH ( $n=1$; age 49 years; male), $\mathrm{NASH}(\mathrm{n}=1$; age 52 years; male).

\section{Isolation of Thy-1 positive cells from human liver tissue Isolation of non-parenchymal cells}

Liver tissue was digested using a modified two-step egtazic acid (EGTA)/collagenase perfusion procedure ${ }^{23}$ to isolate human hepatocytes. Non-parenchymal cells (NPCs) were obtained from the remaining liver tissue based on a protocol described recently. ${ }^{24}$ Briefly, up to $50 \mathrm{~g}$ of tissue was minced and incubated for up to $150 \mathrm{~min}$ under vigorous shaking at $37^{\circ} \mathrm{C}$ in $50 \mathrm{ml}$ isolation buffer $(154 \mathrm{mmol} / \mathrm{l} \mathrm{NaCl}, 5.6 \mathrm{mmol} / \mathrm{l} \mathrm{KCl}$, $5 \mathrm{mmol} / 1$ glucose, $25 \mathrm{mmol} / 1 \mathrm{NaHCO}_{3}, 20 \mathrm{mmol} / \mathrm{l} \mathrm{HEPES}$, $\mathrm{pH}$ 7.4) supplemented with $0.5 \mathrm{mg} / \mathrm{ml}$ collagenase type IV, $0.5 \mathrm{mg} / \mathrm{ml}$ pronase, $40 \mu \mathrm{g} / \mathrm{ml}$ DNase I, $5 \mathrm{mmol} / 1 \mathrm{CaCl}_{2}$ and $1 \mathrm{mmol} / 1 \mathrm{MgCl}_{2}$. Every $30 \mathrm{~min}$ undigested tissue was separated, minced and incubated again. The resulting suspension was filtered (meshes with $210 \mu \mathrm{m}$ and $170 \mu \mathrm{m}$ pore sizes) and washed three times in phosphate-buffered saline (PBS) containing $2 \mathrm{mmol} / \mathrm{l}$ ethylenediaminetetraacetic acid (EDTA). Furthermore, the cell suspension was purified using a $70 \%$ Percoll solution $\left(800 \mathrm{~g}, 30 \mathrm{~min}, 18^{\circ} \mathrm{C}\right)$. After washing with PBS/EDTA, the NPCs were suspended in MACS buffer (PBS containing $2 \mathrm{mmol} / \mathrm{l}$ EDTA, $5 \mathrm{~g} / \mathrm{l}$ bovine serum albumin (BSA)) and stored for up to $20 \mathrm{~h}$ at $4^{\circ} \mathrm{C}$. Size profile of cell fractions was monitored for quality assessment of the dissociation procedure using a cell counter system (Casy Schärfe System, Reutlingen, Germany). NPC fractions were isolated with an average yield of 2.7 (SD 2.6) $\times 10^{6}$ viable cells per $\mathrm{g}$ wet tissue $(\mathrm{n}=39)$.

\section{Purification of Thy- 1 positive cells}

Thy-1 $1^{+}$cells were isolated from NPCs using the immunomagnetic activated cell sorting (MACS) technique (Miltenyi Biotech, Bergisch Gladbach, Germany) according to the instruction manual. Briefly, cells were filtered $(40 \mu \mathrm{m}$ filter, BD Biosciences Europe, Erembodegem, Belgium) and $5 \times 10^{7}$ cells were incubated with $100 \mu \mathrm{l}$ of a mouse anti-CD90 (Thy-1) monoclonal antibody $(\mathrm{mAb})$ for $30 \mathrm{~min}$ at $4^{\circ} \mathrm{C}$. After twofold washing with MACS buffer, cells were incubated with $100 \mu \mathrm{l}$ of goat anti-mouse microbeads for $15 \mathrm{~min}$ at $4^{\circ} \mathrm{C}$ followed by two additional washing steps. Labelled cell suspensions were transferred onto MACS LS columns and washed three times while being located in the magnetic field. Thy $-1^{+}$cells were eluted with $5 \mathrm{ml}$ MACS buffer following removal from the magnet. Cell number and viability were determined by the trypan blue exclusion technique.

\section{Characterisation by flow cytometry}

Cells were suspended in PBS, incubated with fluorescencelabelled $\mathrm{mAb}$ for $30 \mathrm{~min}$ at $4^{\circ} \mathrm{C}$, washed with $\mathrm{PBS}$ and analysed following addition of propidium iodide (PI) $(1 \mu \mathrm{g} / \mathrm{ml}$ PI per 
Table 2 Primer sequences, annealing temperature and expected size of amplified products for polymerase chain reaction (PCR) analysis

\begin{tabular}{|c|c|c|c|c|}
\hline Gene & $\begin{array}{l}\text { Accession } \\
\text { number }\end{array}$ & Primer (forward/reverse) & $\begin{array}{l}\text { Annealing } \\
\text { temperature }\end{array}$ & $\begin{array}{l}\text { Product size } \\
\text { (bp) }\end{array}$ \\
\hline AFP & NM_001134 & $\begin{array}{l}\text { fw TGCAGCCAAAGTGAAGAGGGAAGA } \\
\text { rv ATAGCGAGCAGCCCAAAGAAGAA }\end{array}$ & $55^{\circ} \mathrm{C}$ & 216 \\
\hline Albumin & NM_000477 & $\begin{array}{l}\text { fw GCTGCCATGGAGATCTGCTTGA } \\
\text { rv GCAAGTCAGCAGGCATCTCATC }\end{array}$ & $55^{\circ} \mathrm{C}$ & 174 \\
\hline ChromA & NM_001275 & $\begin{array}{l}\text { fw CGCGCCTTGTCTCCTACTC } \\
\text { rv AGGAAAGAGCCCAGAACAGAT }\end{array}$ & $50^{\circ} \mathrm{C}$ & 254 \\
\hline CK7 & NM_005556 & $\begin{array}{l}\text { fw TCCGCGAGGTCACCATTAAC } \\
\text { rv GCTGCTCTTGGCCGACTTCT }\end{array}$ & $55^{\circ} \mathrm{C}$ & 218 \\
\hline CK14 & NM_000526 & $\begin{array}{l}\text { fw GGGCGGCCTGTCTGTCTC } \\
\text { rv AGGCGGTCATTGAGGTTCTG }\end{array}$ & $60^{\circ} \mathrm{C}$ & 237 \\
\hline CK18 & NM_000224 & $\begin{array}{l}\text { fw CCCGCTACGCCCTACAGA } \\
\text { rv GCGGGTGGTGGTCTTTTG }\end{array}$ & $53^{\circ} \mathrm{C}$ & 248 \\
\hline CK19 & NM_002276 & $\begin{array}{l}\text { fw CGAGCAGAACCGGAAGGATG } \\
\text { rv AGCCGCTGGTACTCCTGATTC }\end{array}$ & $53^{\circ} \mathrm{C}$ & 318 \\
\hline Nestin & NM_006617 & $\begin{array}{l}\text { fw GGGGGCAATGAATCCTCTAG } \\
\text { rv CACCGTATCTTCCСАСCTCTG }\end{array}$ & $50^{\circ} \mathrm{C}$ & 295 \\
\hline$\beta$-Actin & NM_001101 & $\begin{array}{l}\text { fw GCCGGGACCTGACTGACTAC } \\
\text { rv TGCGGATGTCCACGTCAC }\end{array}$ & $53^{\circ} \mathrm{C}$ & 327 \\
\hline
\end{tabular}

$1 \mu \mathrm{g} / \mathrm{ml}$ RNase A) on a FACSCalibur flow cytometer (BD, Heidelberg, Germany) using appropriate regions of interest and/ or quadrant statistics in the compensated fluorescence dot plot diagrams. PI positive, membrane defect cells were excluded. Details concerning the antibodies are given in table 1.

\section{Immunohistochemical staining}

Cryosections $(6 \mu \mathrm{m})$ from snap frozen tissues were fixed in icecold acetone (10 $\mathrm{min})$. For cytospots freshly isolated cells were suspended in PBS, centrifuged $\left(5 \times 10^{4}\right.$ cells) onto glass slides (SuperFrost Plus; Merck) and fixed in acetone. Cultured cells were fixed using 4\% paraformaldehyde for $20 \mathrm{~min}$.

Alkaline phosphatase anti-alkaline phosphatase (APAAP) staining Blocking of slides was performed with $3 \%$ fetal calf serum (FCS) in PBS followed by incubation with primary antibodies for 30 min and a washing step with PBS. For CK14 staining, additional incubation with mouse anti-rabbit immunoglobulins for $30 \mathrm{~min}$ was performed, followed by incubation with rabbit anti-mouse immunoglobulins for $30 \mathrm{~min}$. After incubation with mouse $\operatorname{APAAP}(1: 100$ in $\mathrm{PBS} / 1 \% \mathrm{FCS})$ for $30 \mathrm{~min}$ immunosignals were developed with fast red substrate $(20 \mathrm{~min})$ and counterstained with haematoxylin Quick Stain.

\section{Immunofluorescence staining}

After blocking (3\% dried milk, 0.1\% Triton-X100, PBS) cells were incubated with primary antibodies for $30 \mathrm{~min}$, washed with PBS and incubated with the secondary fluorescenceconjugated antibodies. For co-localisation, steps were repeated with a second set of antibodies. Nuclei were counterstained with $5 \mu \mathrm{g} / \mathrm{ml}$ Hoechst 33258 in PBS.

\section{Determination of mRNA expression by reverse transcription- polymerase chain reaction}

Total RNA was extracted using the RNeasy Mini Kit (Qiagen). First strand cDNA was synthesised using $0.1 \mu \mathrm{g}$ of total RNA and the avian myeloblastosis virus (AMV)-reverse transcription reaction (Promega, Mannheim, Germany) using $15 \mathrm{U}$ AMV reverse transcriptase in a prolonged incubation time of $60 \mathrm{~min}$.
The polymerase chain reaction (PCR) was performed according to the manufacturer's instructions (Invitrogen, Karlsruhe, Germany) using primers as listed in table 2. After an initial denaturation step of $3 \mathrm{~min}$ at $94^{\circ} \mathrm{C}$, amplification was performed for 35 cycles at $94^{\circ} \mathrm{C}$ for $45 \mathrm{~s}, 30 \mathrm{~s}$ at the optimal annealing temperature and $72^{\circ} \mathrm{C}$ for $30 \mathrm{~s}$. The PCR was terminated by a final elongation step at $72{ }^{\circ} \mathrm{C}$ for $10 \mathrm{~min}$. Amplified products were transferred on $1.5 \%$ agarose gels for electrophoresis followed by ethidium bromide staining.

\section{Cell culture}

Freshly isolated Thy-1+ ${ }^{+}$cells were resuspended in adhering medium (William's E medium, 5\% FCS, $10 \mathrm{mmol} / \mathrm{l}$ nicotinamide, $20 \mathrm{mmol} / \mathrm{l}$ HEPES, $17 \mathrm{mmol} / \mathrm{l} \mathrm{NaHCO}_{3}, 550 \mathrm{mg} / \mathrm{l}$ sodium pyruvate, $0.2 \mathrm{mmol} / 1$ ascorbic acid 2-phosphate, $14 \mathrm{mmol} / \mathrm{l}$ glucose, $10^{-7} \mathrm{~mol} / \mathrm{l}$ dexamethasone, $6.25 \mu \mathrm{g} / \mathrm{ml}$ insulin, $6.25 \mu \mathrm{g} / \mathrm{ml}$ transferrin, $6.25 \mathrm{ng} / \mathrm{ml}$ sodium selenite, $1.25 \mathrm{mg} / \mathrm{ml}$ BSA and $5.35 \mu \mathrm{g} / \mathrm{ml}$ linoleic acid, $100 \mathrm{U} / \mathrm{ml}$ penicillin, $100 \mu \mathrm{g} / \mathrm{ml}$ streptomycin) and plated onto collagen coated dishes (BD Biosciences Europe) at a density of $5 \times 10^{4} / \mathrm{cm}^{2}$. After 3-5 days the medium was replaced with culture medium (adhering medium without FCS, $20 \mathrm{ng} / \mathrm{ml}$ epidermal growth factor (EGF)). The medium was changed once a week. Viability and cell growth during the culture period were monitored by cell morphology.

\section{Transplantation of hepatic progenitor cells}

All animal housing and experimentation procedures were in accordance with German legislation on animal protection (latest version). Pfp/Rag2 ${ }^{-/-}$mice (malfunction of NK cell, T and B cell depletion) were obtained at 8 months of age from Taconic (Lille Skensved, Denmark). The cellular transplantation model was performed as described recently. ${ }^{25}$ Briefly, recipient liver regeneration was inhibited by treating the mice with monocrotalin (30 mg/kg body weight; intraperitoneally) 6 and 4 weeks prior to transplantation. After partial hepatectomy, $1 \times 10^{6}$ human Thy-1 positive liver cells were administered by intrasplenic injection. Livers were removed after 7 weeks and fixed in $4 \%$ formaldehyde and paraffin embedded for further analysis. 

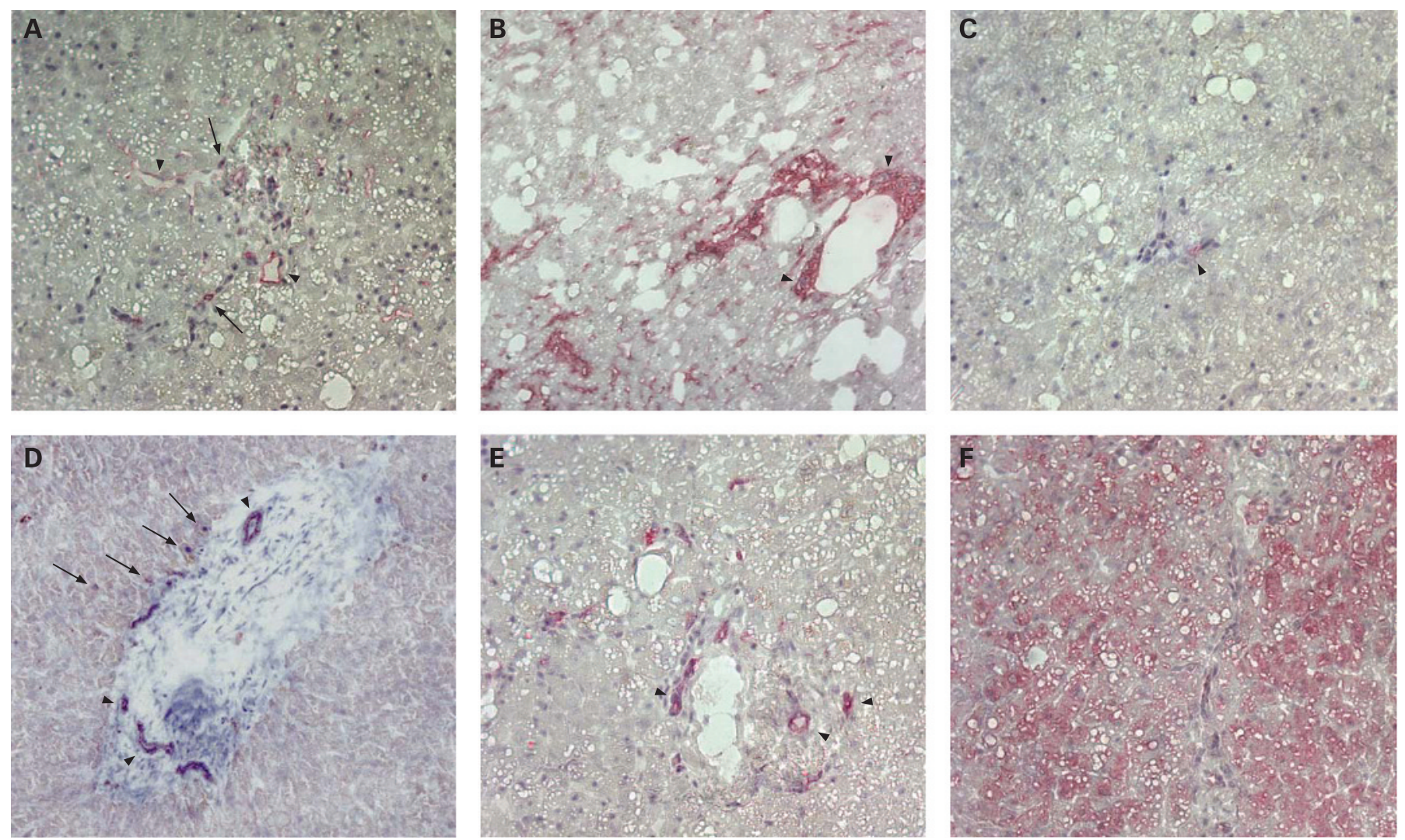

Figure 1 Immunohistochemical staining of human liver sections (from a patient with alcoholic fatty liver disease) for markers of progenitor, hepatic and biliary cells. (A) Immunostaining for CD34 was found on endothelial cells lining the vascular structures of the portal tract (arrow head) and sparely on some cells in adjacent liver (arrow). (B) Positive staining for Thy- $1^{+}$was found in the portal tract area and for some parenchymal cells (arrow head). (C) Only spare positive immunostaining could be detected for c-kit expressing cells. (D) OV6 ${ }^{+}$cells were mainly detected in parenchyma surrounding the portal area (arrow) and in bile duct (arrow head). (E) Bile duct cells were immunoreactive for CK19 (arrow head), whereas (F) CK18 was found on hepatocytes and bile duct cells. (A-F: original magnification, $\times 200)$.

\section{RESULTS}

\section{Expression of progenitor cell marker in human liver sections}

Expression analysis of markers described for liver progenitors were performed in cryo-sections of adult liver tissue from a patient with fat liver disease. Immunoreactivity for CD34 was found in endothelial cells lining the vascular structures of the portal tract and sparely on cells in the adjacent parenchyma (fig 1A), whereas c-kit expression was barely detected (fig 1C). Thy-1 expression was found in the portal tract area and in scattered cells in the surrounding parenchyma (fig 1B). Expression of the oval cell marker OV6 was detected on epithelial cells adjacent to the portal tract, but primarily on bile duct cells (fig 1D). Specific immunostaining of CK19 for biliary epithelial cells (fig 1E), CK18 for bile duct epithelium and parenchymal hepatocytes (fig $1 F$ ) is also demonstrated.

\section{Cells of adult human non-parenchymal liver cell fractions express stem cell markers}

Fractions of small liver cells separated from hepatocytes were isolated from discarded surgical adult human liver tissue after performing a multi-step isolation process (fig 2A-B). Immunocytochemical analysis of small liver cell fractions revealed a high percentage of non-parenchymal cells (Kupffer, stellate and endothelial cells; data not shown) and are therefore termed the non-parenchymal cell (NPC) fraction. NPC fractions were investigated by flow cytometry for expression of surface markers, which have been detected on liver progenitor cells by immunohistochemistry. Cells were found positive for CD34 (6\% (SD 4\%), n=18), CD117 (8\% (SD 7\%), $\mathrm{n}=18)$ and CD90 ( $9 \%$ (SD 6\%), $\mathrm{n}=22$ ). Additionally, double immunostaining revealed, that $2 \%(\mathrm{SD} 2 \%)(\mathrm{n}=11)$ of NPC fractions were $\mathrm{CD}^{2} 4^{+} / \mathrm{CD} 90^{+}, 2 \%(\mathrm{SD} 2 \%)(\mathrm{n}=9)$ were $\mathrm{CD} 34^{+} / \mathrm{CD}_{117^{+}}$and $3 \%(\mathrm{SD} 1 \%)(\mathrm{n}=5)$ were $\mathrm{CD} 90^{+} / \mathrm{CD} 117^{+}$.

\section{Thy-1 positive cells express markers of liver progenitor cells}

Thy-1 (CD90), the most abundant progenitor marker on NPC fractions, was selected as a marker for immuno-magnetic activated cell sorting (MACS). Subsequently, fluorescenceactivated cell sorting (FACS) analysis was performed determining the quantity and characteristics of Thy-1 isolated cells. MACS sorted cells were highly positive for Thy-1 (83\% (SD $7 \%), \mathrm{n}=6)$ and co-expressed CD34 (24\% (SD 9\%), $\mathrm{n}=5)$ and hardly CD117 (1.8\% (SD 0.7\%), n= 5) (fig 2C-E). Additionally, we found expression of CD45 (35\% (SD 9\%), n = 5), CD14 $(20 \%$ (SD 7\%), $n=5)$ and CD3 (29\% (SD 9\%), n=5) on some Thy-1+ cells. The overall outcome of viable Thy- $1^{+}$cells after MACS isolation was 1.4 (SD 0.9$) \times 10^{4}$ per $10^{6}$ NPCs $(n=39)$. Furthermore, performing a correlation study we found a significant higher rate of Thy- $1^{+}$cells in tissues, in which regenerative events; for example, slight histological signs of hepatitis, fibrosis, or cirrhosis, were described (1.8\% (SD 1.0\%) of NPCs, $\mathrm{n}=20$ ) than in non-regenerating tissue (1.2\% (SD $0.57 \%$ ) of NPCs, $n=19$ ) (fig $2 \mathrm{G}$ ). The rates of Thy- $1^{+}$cells were not correlated with expression of CD45, CD14 and CD3 (data 

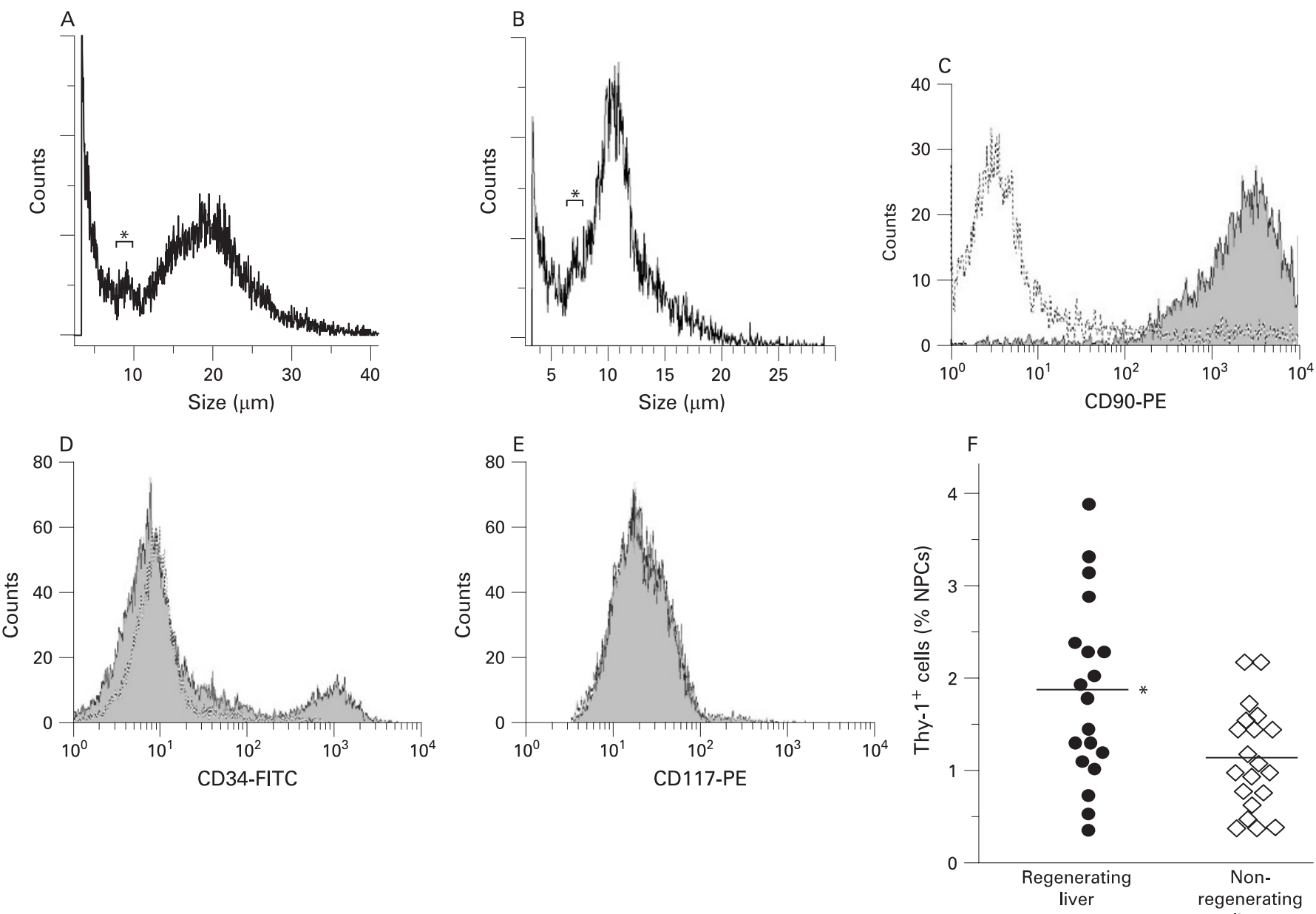

Figure 2 Isolation and characterisation of progenitor cell fractions from human liver tissue. Size profiles of Percoll purified liver cell fractions show (A) Hepatocytes (diameter, 20 (SD 5) $\mu \mathrm{m}$ ) separated from (B) smaller liver cells (diameter, 8-13 $\mu \mathrm{m}$ ). Fractions of dead cells are indicated by an asterisk and cell debris is found at particle sizes of below $6 \mu \mathrm{m}$. The Thy-1 positive cells isolated by using immuno-magnetic activated cell sorting (MACS) were further characterised by fluorescence-activated cell sorting (FACS) analysis for their expression of (C) CD90, (D) CD34, and (E) CD117. Data are from one analysis representative of five independent experiments. Unfilled curve: before MACS isolation; filled curve: after MACS isolation. (F) Thy $-1^{+}$cells were further purified by MACS and their outcome was correlated to the underlying disease. The tissues were categorised to regenerating $(n=20)$ and non-regenerating $(n=19)$ liver from patients with cirrhosis, fibrosis, alcoholic liver disease (ALD), non-alcoholic fatty liver disease (NAFLD) and colorectal liver metastases, respectively. ${ }^{*} p<0.05$, differs from non-regenerating liver tissue. FITC, fluorescein isothiocyanate; NPCs, non-parenchymal cells; PE, phycoerythrin.

not shown). A more detailed analysis with type of disease, tissue damage and patient related data did not show any correlation to the rate of Thy- $1^{+}$cells (data not shown).

Expression of progenitor and hepatic cell markers were determined on freshly isolated Thy-1+ $1^{+}$cells by immunostaining (fig 3). About $60 \%$ of the Thy-1+-sorted cells demonstrated positivity for liver progenitor markers CK14, M2PK, OV6 and biliary/progenitor marker CK19 (fig 3A). Double immunofluorescence staining of Thy- $1^{+}$cells revealed co-localisation of CK14 with CD117, CD34 (liver progenitor and HSC), CK19 (bile duct/progenitor cell), HepPar1 (hepatocyte) and OV6 (fig 3B). mRNA analyses of the Thy-1+ $1^{+}$cell population from 27 donors confirmed the expression of CK14. Also, we detected two additional progenitor genes expressed in Thy-1 $1^{+}$cells of all donors, chromogranin A (pancreatic) and nestin (neural) (fig 4). Positive gene expression was also found for hepatocyte markers CK18 and albumin (10 of 27), as well as biliary marker CK19, but not for CK7. alpha-fetoprotein (AFP) was not detected in any of the cell preparations (fig 4).
Thy-1 positive liver cells in culture show differentiation towards hepatocytes and bile duct cells

Thy $-1^{+}$cells were seeded on collagen-coated culture dishes and maintained in culture under conditions described for hepatocyte growth. ${ }^{27}$ Efficiency of plating was sufficient and after 10 14 days cells started to grow into colonies (fig $5 \mathrm{~A}-\mathrm{C}$ ). At day 28 of culture an almost complete monolayer was formed (fig 5D). Furthermore, mRNA analyses by reverse transcription polymerase chain reaction (RT-PCR) were performed throughout culturing and differences in gene expression were observed depending on the culture period (fig $5 \mathrm{G}$ ). The hepatic marker CK18 strongly increased from day 14 to 28 , whereas albumin could not be detected. Furthermore, CK19 expression was almost unchanged up to day 28 , while the gene expression of the bile duct marker CK7 was clearly enhanced. In contrast, a reduction of the progenitor markers CK14, chromogranin A and nestin was observed as a function of time in culture. AFP was not expressed either in fresh or in cultured cells. In addition, Thy- $1^{+}$cells cultured for 14 days were stained with antibodies 
Figure 3 Immunocytochemical staining of Thy $-1^{+}$cells for liver progenitor and hepatic markers. (A) Cytospots of Thy-1sorted cells were stained for liver progenitor makers such as CK14, M2PK, OV6 and the biliary marker CK19 (original magnification, $\times 200$ ). (B) Double immunofluorescence staining of Thy-1sorted cells was performed to detect colocalisation of liver progenitor marker CK14 with markers specific for haematopoietic stem cells (HSCs) and liver progenitors (CD177, CD34), bile duct cells (CK19), hepatic cells (HepPar1) and oval cells (OV6) (original magnification, $\times 400)$.
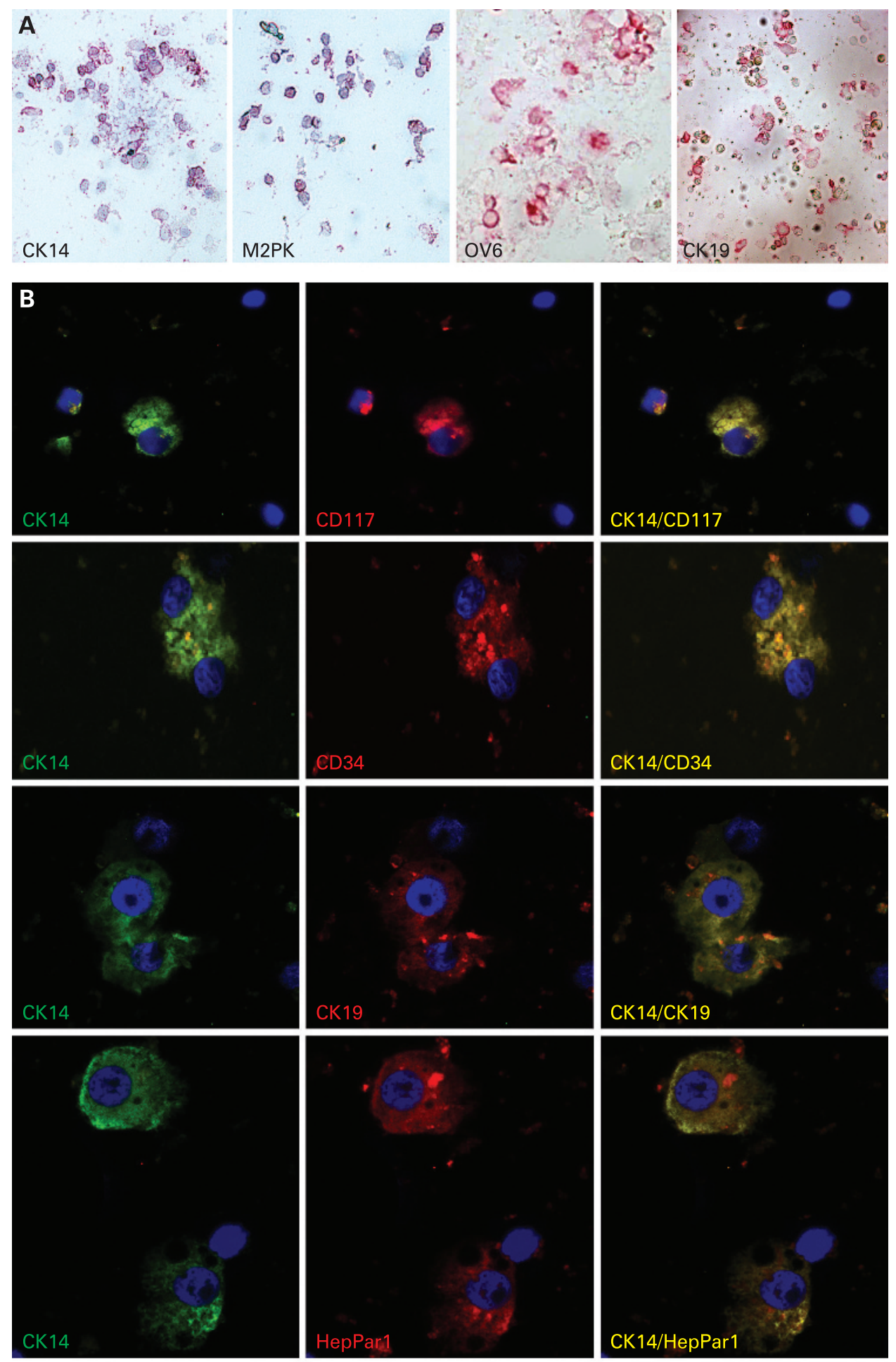

CK14/CK19
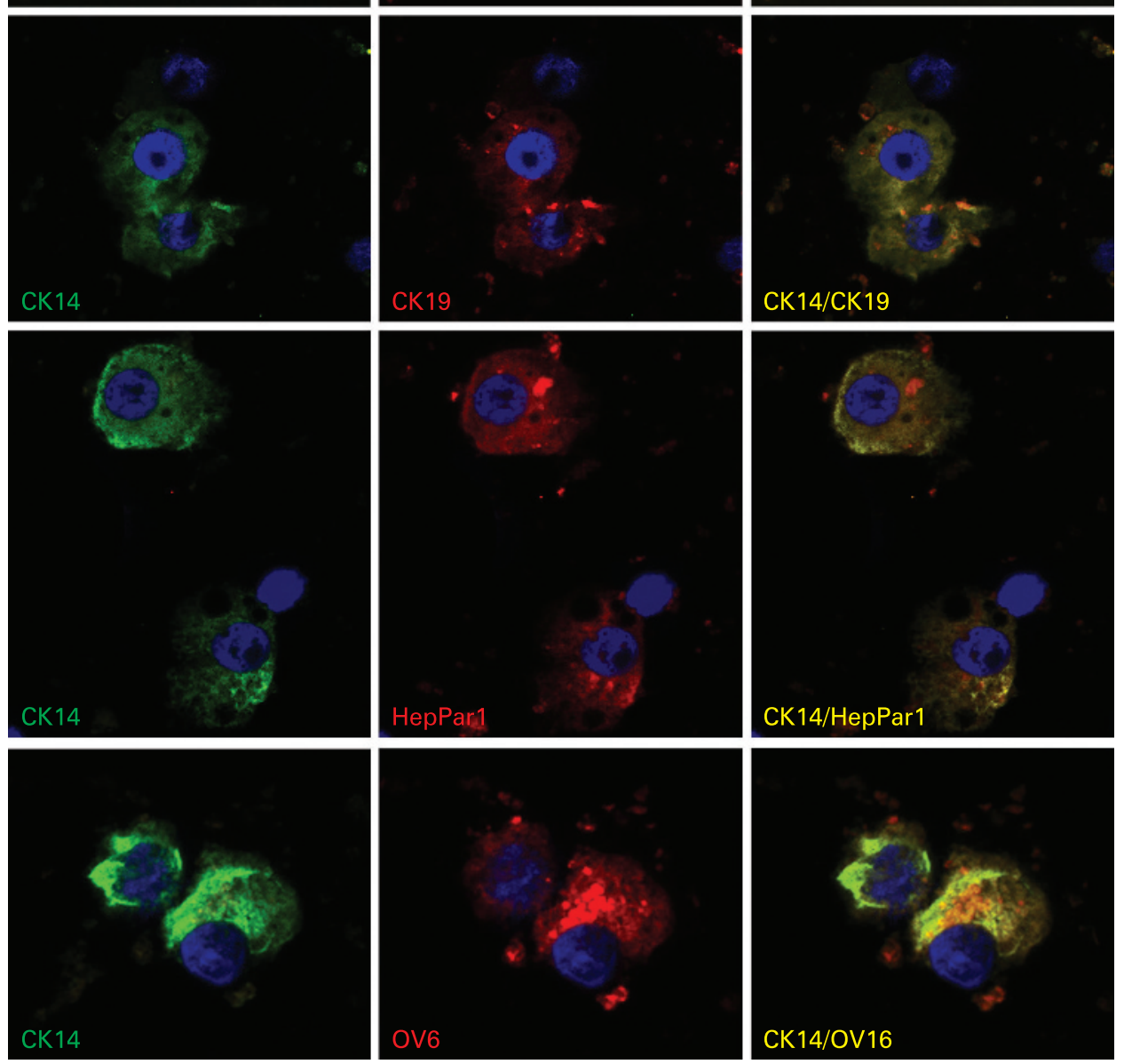


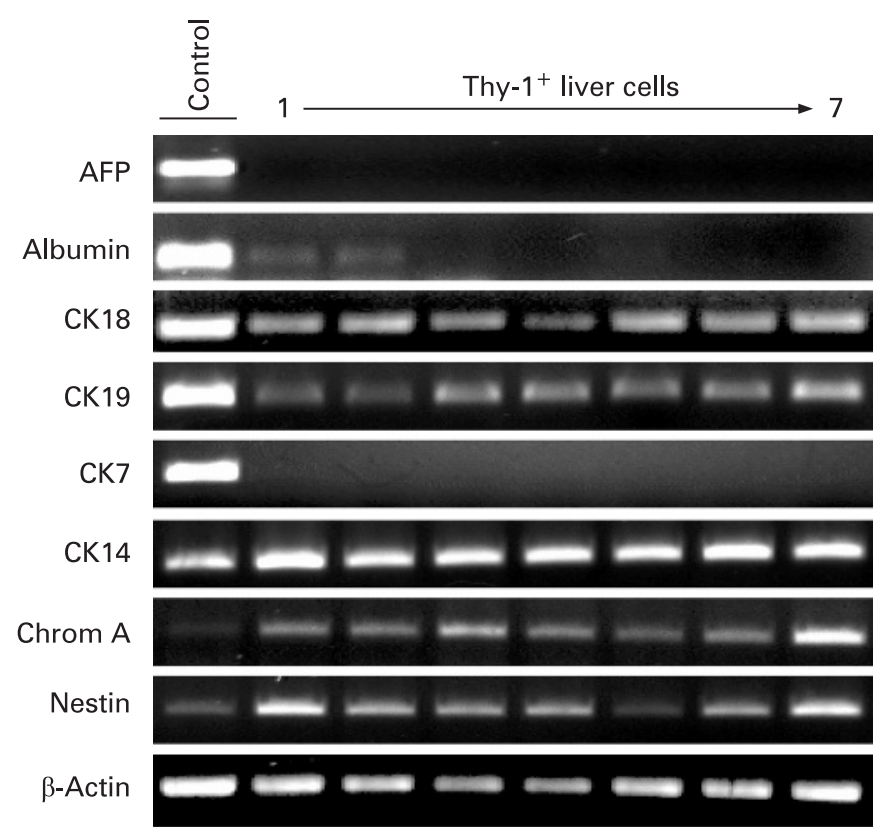

Figure 4 Semiquantitative reverse transcription-polymerase chain reaction (RT-PCR) analysis of mRNAs from Thy-1 sorted liver cells of seven representative different donors. Gene expression of hepatic (alphafetoprotein (AFP), albumin, CK18), bile duct (CK19, CK7), liver progenitor (CK14), pancreatic (chromogranin A) and neural (nestin) cell markers were investigated. The following samples were used for controls: AFP, CK14, $\beta$-actin (hepatocellular carcinoma), albumin, CK18 (human hepatocytes), CK19, CK7 (cholangiocarcinoma), chrom A (Panc-1 cell line) and nestin (glioblastoma).

against HepPar1 and CK7 and demonstrated expression of hepatocyte and bile duct specific proteins, respectively (fig 5E,F).

\section{Transplanted Thy-1 positive cells demonstrate engraftment in mouse livers}

Integration of transplanted Thy- $1^{+}$cells was studied using a mouse transplantation model, which impedes proliferation of residual hepatocytes after partial hepatectomy and therefore supply transplanted Thy-1+ $1^{+}$cells with a growth advantage over host hepatocytes. ${ }^{25}$ Seven weeks after transplantation human hepatic cells were detected in the mouse liver background by staining with HepPar1 (human hepatocyte specific antigen) antibody (fig 6A-C), which showed no relevant cross-reactivity for murine antigens. In cryosections of the respective materials, human albumin, a marker of functional activity and hepatocyte differentiation was also detected (fig 6D,E). HepPar1 and albumin positive cells were localised in the periportal region, demonstrating a predominant periportal engraftment of transplanted Thy-1+ liver cells. After transplantation into mouse liver Thy- $1^{+}$sorted cells featured a typical human hepatocytic phenotype indicating integration of the transplanted cells within the mouse liver.

\section{DISCUSSION}

The objective of this paper was to determine whether Thy-1 positive cells (1) were found in and could be isolated from human liver tissue; (2) demonstrate multiple lineage markers common with a progenitor phenotype; and (3) have the potential for cellular treatment in liver regeneration. The data presented show that adult human liver harbours Thy-1 positive cells which express hepatocellular and biliary markers representing their bipotential character. These cells have a repopulation capacity after transplantation and therefore resemble a liver progenitor cell type.

Because of their anatomical homology, both adult and fetal livers have been considered to harbour progenitor cells in the ductules/canals of Hering at the interface between the parenchymal and the portal tract mesenchyme. ${ }^{28}$ These progenitor cells were defined in humans based on immunohistochemical studies as larger than $6 \mu \mathrm{m}$ and less than $40 \mu \mathrm{m}$ in diameter, ${ }^{7}$ which agrees with the isolated progenitor cell fraction (10 (SD 3) $\mu \mathrm{m})$ in this study and, furthermore, might correspond in size to progenitor cells isolated from rat (8$10 \mu \mathrm{m})^{29}$ and mouse $(7-15 \mu \mathrm{m}) .^{30}$ The isolated small liver cells partly showed co-expression of CD34, c-kit and Thy-1, which are markers of the haematopoietic compartment and were described as being present in human ${ }^{13} 14$ and rodent liver. ${ }^{31}$ Furthermore, we found some Thy $-1^{+}$cells positive for CD45 which was also reported earlier by others using human fetal ${ }^{14}$ and murine liver. ${ }^{30}$ CD45 positivity, in general, indicates a haematopoietic lineage, ${ }^{32}$ but recent reports clearly show that hepatic side-population cells, a further characteristic of progenitor cells, ${ }^{33}$ both CD45 positive and negative, can differentiate into hepatic cells expressing HepPar1 and albumin ${ }^{20}$ and upon transplantation into a mouse model, can contribute to liver regeneration. ${ }^{34}$ Therefore, the CD45 surface antigen expression status is suggested as not important in terms of the hepatic differentiation potential. Additionally, by using immunohistochemistry we found Thy-1 and CD34 expressed on endothelial cells lining the vascular structures of the portal tract which might correspond to a stem cell niche of the mesenchymal compartment giving rise to mesodermal and epithelial tissue as suggested earlier. ${ }^{14}$

\section{Thy1 $^{+}$cells in human liver feature bipotential progenitor cells with hepatic characteristics}

Progenitor cells are often recognised by expression of organ specific fetal proteins, which demonstrate their early status in development. Isolated human Thy- $1^{+}$cells showed specific expression of M2PK, the fetal M2 isoform of pyruvate kinase (M2PK), which is considered as a marker for liver progenitor cells, not expressed in adult hepatocytes and ductal cells. ${ }^{12}$ Furthermore, we did not find mRNA expression of AFP, a serum glycoprotein produced by hepatoblasts during the fetal development, a defining feature of progenitor cells in many rodent models of injury ${ }^{7}$ and in human fetal livers. ${ }^{14}$ On the other hand, it was reported that AFP in progenitor cells from adult human liver was only occasionally observed ${ }^{7}$ and it was recently shown that during progenitor cell activation in a rat model, the non-ductular progenitor cells expressing nestin and Thy-1 were negative for AFP. ${ }^{35}$

A characteristic of liver progenitor cells is the co-expression of different cell specific proteins enabling a differentiation into hepatic and/or biliary epithelial cells. We could demonstrate that the biliary marker CK19 as well as the oval cell marker OV6 ${ }^{36}$ were not only detected on bile duct cells by immunohistology, but also were present on Thy- $1^{+}$cells indicating these markers as liver progenitor markers as suggested before for CK $19^{7}$ and OV6. ${ }^{37}$ The bipotential nature of Thy- $1^{+}$cells is shown by expression of CK19 and HepPar1, antigens identified on liver progenitor cells during early stages of gestation. ${ }^{38}$ Enhanced or reduced expression of either markers commits to biliary or hepatocyte epithelial cell lineages. HepPar1 antibodies recognise the mitochondrial fraction of human hepatocytes and do not label haematopoietic or non-parenchymal cells. ${ }^{39}$ Further 

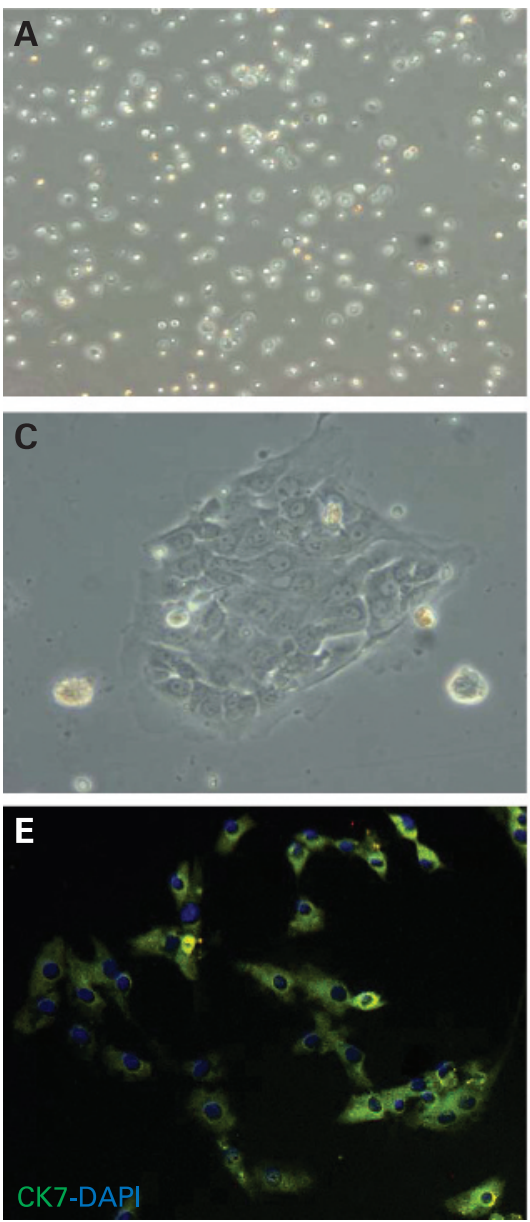
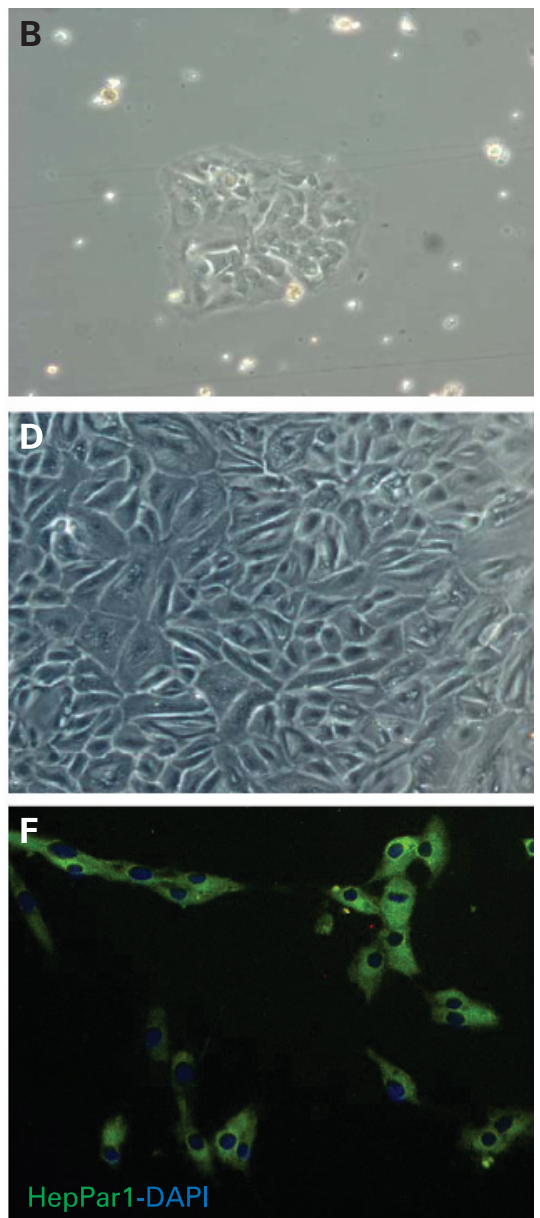

G

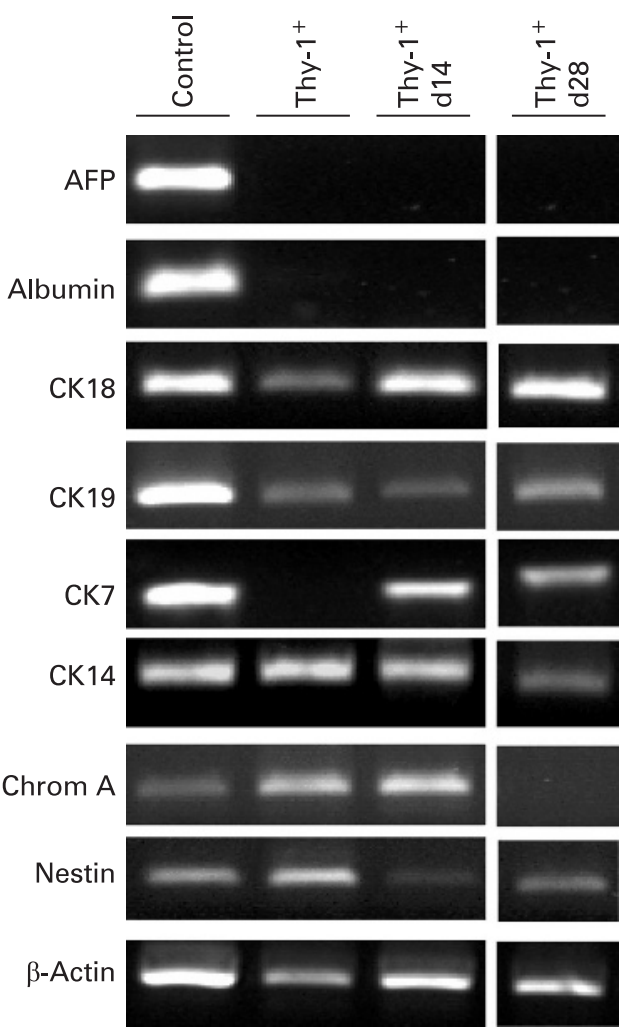

Figure 5 Culture of Thy-1 positive liver cells and semiquantitative reverse transcription-polymerase chain reaction (RT-PCR) analysis of mRNAs. Cells plated on collagen-coated dishes after (A) day 1 showing singular cells, (B) day 10 and (C) day 15 forming small colonies. After cultivation until day 28 (D), a complete monolayer was formed, containing cells with mature hepatic morphology. Immunocytochemical staining of cultured Thy-1 positive cells at day 14 was performed for (E) bile duct (CK7) and (F) hepatic (HepPar1) cell markers. (Original magnification, $\times 200$; seven independent experiments in triplicates.) (G) Gene expression of hepatic (alpha-fetoprotein (AFP), albumin, CK18), bile duct (CK19, CK7), liver progenitor (CK14), pancreatic (chromogranin A) and neural (nestin) mRNA markers were studied during culture of Thy-1-sorted liver cells. Control samples were used as indicated in fig 4 ( $\beta$-actin as positive control; four independent experiments in triplicates). DAPI, 4',6-diamidine-2' -phenylindole.

evidence suggesting Thy- $1^{+}$cells as bipotential liver progenitors comes from our RT-PCR analysis which showed expression of the biliary lineage marker CK19 as well as hepatocytic lineage marker CK18 and partly albumin. Additionally, Thy- $1^{+}$cells revealed expression of the neuroendocrine marker chromogranin $\mathrm{A}^{28}$ and neural progenitor cell marker nestin, ${ }^{40}$ both suggested as marker proteins of bipotential liver progenitors. Expression of these markers has also been seen on differentiated cells from the haematopoietic lineage and therefore may indicate a relationship between the haematopoietic system and liver cell lineage either originating from or both having a common ancestor during the fetal liver development when haematopoietic cells colonise the liver. ${ }^{16}$ Furthermore, CK14 has been described as a marker of bipotential liver progenitors and was detected in human regenerating livers after massive necrosis. ${ }^{38}{ }^{41}$ Although it was reported that OV6 antibodies in rat liver recognise an epitope common to both CK19 and CK14 present on rodent progenitor cells, ${ }^{42}$ in human tissue controversial data about specificity are reported describing expression patterns of OV6 and CK19 as non-coincidental ${ }^{43}$ and of OV6 and CK14/CK19 as similar. ${ }^{41}$ We found that Thy-1 ${ }^{+}$cells demonstrate double immuno-positivity for CK14 and CK19 as well as CK14 and OV6 suggesting co-expression of these markers on Thy- $1^{+}$cells.
Co-expression of CK14, CK19 and positivity for OV6 of Thy-1+ cells might indicate a similarity of human progenitor cells to the progenitor cell development in rodents as it was postulated in human fetal liver. ${ }^{14}$ Our findings of Thy- $1^{+}$cells isolated from adult human liver tissue and expressing a variety of progenitor, biliary and hepatocytic markers might correspond to a more accepted understanding that human liver progenitor cells do not represent a single, defined cell type but rather a range of cells of intermediate hepatobiliary phenotype.

Thy- $1^{+}$progenitor cells may differentiate into hepatic cells and repopulate a host liver

Activation and expansion of liver progenitor cells is dependent on a specific microenvironment involving multiple growth modulators, which are likely to be mimicked in a variety of in vitro models. ${ }^{44}$ Using a protocol for hepatocyte expansion ${ }^{27}$ we could induce proliferation of Thy- $1^{+}$cells in vitro, which was paralleled by differentiation into hepatocytic but also biliary lineage without favouring one of each other. During culture expression of progenitor markers (chromogranin A, nestin, CK14) decreased and both hepatocytic and biliary markers increased, which may resemble a process of liver development. Furthermore, it is suggested that progenitor cells losing CK14 
Figure 6 Transplantation of Thy-1 positive liver cells into a mouse model. Freshly isolated Thy-1-sorted cells were delivered to the liver of Pfp/Rag2 ${ }^{-1-}$ mice by transplenic application. Animals were sacrificed 7 weeks after transplantation. Transplanted human cells were detected in cryo-sections (A-E) by immunohistochemistry expressing the human hepatocyte specific marker HepPar1 $(A-C)$ and the functional marker human albumin $(\mathrm{D}, \mathrm{E})$. Engrafted cells were found predominantly in the periportal region and partly scattered throughout the parenchyma (arrow head). A negative control is represented by a non-transplanted animal immunostained for human albumin $(F)$. $(A, D$ : original magnification, $\times 100 ; B, E, F$, original magnification, $\times 200$; C: original magnification, $\times 400$ ).
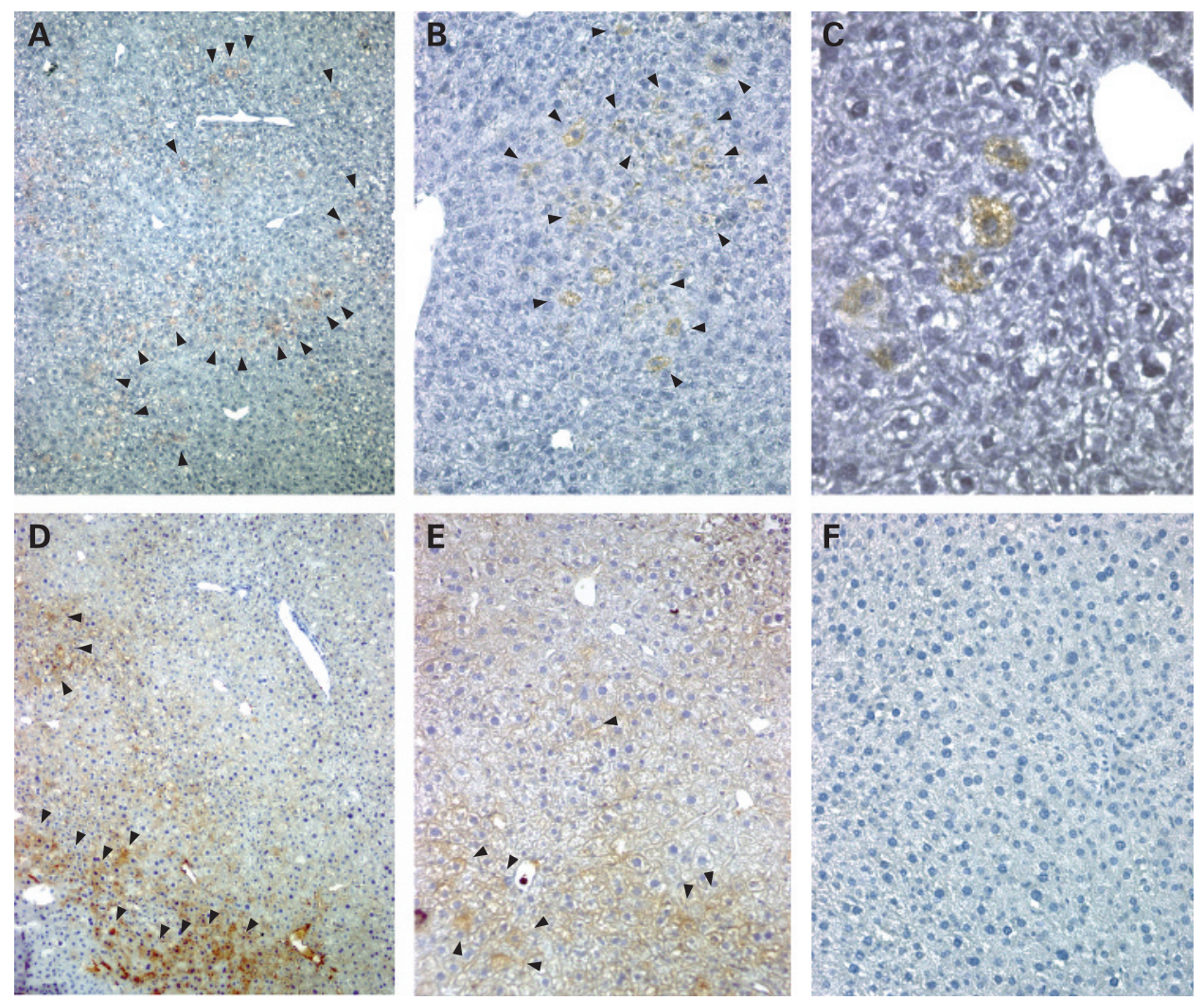

expression become committed to either hepatocyte or biliary epithelial cell lineages. ${ }^{38}$ Interestingly, CD34 ${ }^{+}$and $\mathrm{c}-\mathrm{kit}^{+}$cells isolated from adult human liver were shown to differentiate only into biliary epithelial cell lineage based on a biliary cell growth media, ${ }^{13}$ which did have an impact on the differentiation of Thy- $1^{+}$cells in this study (data not shown).

To further assess the participation of transplanted Thy $-1^{+}$ cells in liver regeneration a mouse model for cell transplantation after partial hepatectomy was used..$^{25}$ Interestingly, freshly isolated Thy-1 ${ }^{+}$cells showed a weak or negative albumin expression. After transplantation the cells showed clear albumin expression even though it was not detectable during culture. Studies for in vitro differentiation of progenitor cells may not $^{141945}$ or do lead to expression of functional genes such as albumin $^{19} 45$ depending on specific culture conditions. After transplantation and the under influence of a variety of factors in vivo, differentiation of progenitors is seen from low or none to albumin expressing cells even in a xenogenic model. ${ }^{19}{ }^{45}$ However the repopulation efficiency was quite low (about $3 \%)$ to replace cells and reverse a pathological condition, ${ }^{46}$ but was within the range of published data for liver cell engraftment in xenogenic models. One reason might be murine liver failing the proper microenvironment for the human cells and therefore no cell cluster formation was seen.

Human bipotential liver progenitor cells would be an invaluable therapeutic tool to induce liver regeneration or to support liver function by cell transplantation, because of the increasing disparity between the increase in end stage liver diseases and the shortage of suitable donor organs. This study might suggest a strategy of isolating progenitor cells from resected, slightly diseased, liver tissue followed by an autogenic re-transplantation of, for example, genetically altered cells to enrich the regenerative potential. Future research on human adult liver progenitor cells should address the question of separation of different subpopulations, their specific capabilities for expansion in vitro and their applicability for transplantation.

Acknowledgements: We gratefully acknowledge the technical assistance of Anja Gräbe, Center of Liver Cell Research, University of Regensburg, Germany.

Funding: This work was supported by a fellowship of the medical department, University of Regensburg (ReForM-C program).

Competing interests: None

Ethics approval: Use of human tissue samples in this study was approved by the ethics committee of the University of Regensburg. All housing and experimental procedures using animals were in accordance with the most recent German legislation concerning animal protection.

\section{REFERENCES}

1. Michalopoulos GK, DeFrances MC. Liver regeneration. Science 1997;276:60-6.

2. Fausto N. Liver regeneration and repair: hepatocytes, progenitor cells, and stem cells. Hepatology 2004:39:1477-87.

3. Sell S. Heterogeneity and plasticity of hepatocyte lineage cells. Hepatology 2001:33:738-50.

4. Roskams T. Progenitor cell involvement in cirrhotic human liver diseases: from controversy to consensus. J Hepatol 2003;39:431-4.

5. van Eyken $\mathbf{P}$, Sciot R, van Damme B, et al. Keratin immunohistochemistry in normal human liver. Cytokeratin pattern of hepatocytes, bile ducts and acinar gradient. Virchows Arch A, Pathol Anat Histopathol 1987;412:63-72.

6. Paku S, Schnur J, Nagy P, et al. Origin and structural evolution of the early proliferating oval cells in rat liver. Am J Pathol 2001;158:1313-23.

7. Roskams TA, Theise ND, Balabaud C, et al. Nomenclature of the finer branches of the biliary tree: canals, ductules, and ductular reactions in human livers. Hepatology 2004;39:1739-45.

8. Roskams T, Yang SO, Koteish A, et al. Oxidative stress and oval cell accumulation in mice and humans with alcoholic and nonalcoholic fatty liver disease. Am J Pathol 2003;163:1301-11

9. Theise ND, Saxena R, Portmann BC, et al. The canals of Hering and hepatic stem cells in humans. Hepatology 1999;30:1425-33.

10. Fausto $\mathbf{N}$, Campbell JS. The role of hepatocytes and oval cells in liver regeneration and repopulation. Mech Dev 2003:120:117-30.

11. Forbes S, Vig P, Poulsom R, et al. Hepatic stem cells. J Pathol 2002;197:510-8.

12. Lowes KN, Brennan BA, Yeoh GC, et al. Oval cell numbers in human chronic liver diseases are directly related to disease severity. Am J Pathol 1999;154:537-41. 
13. Crosby HA, Kelly DA, Strain AJ. Human hepatic stem-like cells isolated using c-kit or CD34 can differentiate into biliary epithelium. Gastroenterology 2001;120:534-44.

14. Masson NM, Currie IS, Terrace JD, et al. Hepatic progenitor cells in human fetal liver express the oval cell marker Thy-1. Am J Physiol Gastrointest Liver Physiol 2006;291:G45-54.

15. Theise ND, Nimmakayalu M, Gardner R, et al. Liver from bone marrow in humans. Hepatology 2000;32:11-6.

16. Thorgeirsson SS, Grisham JW. Hematopoietic cells as hepatocyte stem cells: a critical review of the evidence. Hepatology 2006;43:2-8.

17. Wang $\mathbf{X}$, Willenbring $H$, Akkari $Y$, et al. Cell fusion is the principal source of bonemarrow-derived hepatocytes. Nature 2003;422:897-901.

18. Walkup MH, Gerber DA. Hepatic stem cells: in search of. Stem Cells 2006;24:1833-40.

19. Dan YY, Riehle KJ, Lazaro C, et al. Isolation of multipotent progenitor cells from human fetal liver capable of differentiating into liver and mesenchymal lineages. Proc Natl Acad Sci U S A 2006;103:9912-7.

20. Hussain SZ, Strom SC, Kirby MR, et al. Side population cells derived from adult human liver generate hepatocyte-like cells in vitro. Dig Dis Sci 2005:50:1755-63.

21. Fiegel HC, Gluer $S$, Roth $B$, et al. Stem-like cells in human hepatoblastoma. $J$ Histochem Cytochem 2004;52:1495-501.

22. Thasler WE, Weiss TS, Schillhorn K, et al. Charitable state-controlled foundation human tissue and cell research: ethics and legal aspects in the supply of surgically removed human tissue for research in the academic and commercial sector in Germany. Cell and Tissue Banking 2003:4:49-56.

23. Weiss TS, Pahernik S, Scheruebl I, et al. Cellular damage to human hepatocytes through repeated application of 5-aminolevulinic acid. J Hepatol 2003:38:476-82.

24. Fabris L, Strazzabosco M, Crosby HA, et al. Characterization and isolation of ductular cells coexpressing neural cell adhesion molecule and $\mathrm{Bcl}-2$ from primary cholangiopathies and ductal plate malformations. Am J Pathol 2000;156:1599-612

25. Witek RP, Fisher SH, Petersen BE. Monocrotaline, an alternative to retrorsine-based hepatocyte transplantation in rodents. Cell Transplant 2005:14:41-7.

26. Aurich I, Mueller LP, Aurich $\mathrm{H}$, et al. Functional integration of hepatocytes derived from human mesenchymal stem cells into mouse livers. Gut 2007:56:405-15.

27. Lazaro CA, Croager EJ, Mitchell C, et al. Establishment, characterization, and longterm maintenance of cultures of human fetal hepatocytes. Hepatology 2003;38:1095-106

28. Roskams T. Different types of liver progenitor cells and their niches. J Hepatol 2006;45:1-4

29. Dabeva MD, Hwang SG, Vasa SR, et al. Differentiation of pancreatic epithelial progenitor cells into hepatocytes following transplantation into rat liver. Proc Natl Acad Sci U S A 1997:94:7356-61.

30. Wang $\mathbf{X}$, Foster $\mathrm{M}, \mathrm{Al}$ Dhalimy $\mathrm{M}$, et al. The origin and liver repopulating capacity of murine oval cells. Proc Natl Acad Sci U S A 2003:100(Suppl 1):11881-8.
31. Petersen BE, Goff JP, Greenberger JS, et al. Hepatic oval cells express the hematopoietic stem cell marker Thy-1 in the rat. Hepatology 1998;27:433-45

32. Knapp W, Dorken B, Rieber P, et al. CD antigens 1989. Blood 1989;74:1448-50.

33. Shimano K, Satake M, Okaya A, et al. Hepatic oval cells have the side population phenotype defined by expression of ATP-binding cassette transporter ABCG2/BCRP1. Am J Pathol 2003;163:3-9.

34. Wulf GG, Luo KL, Jackson KA, et al. Cells of the hepatic side population contribute to liver regeneration and can be replenished with bone marrow stem cells. Haematologica 2003;88:368-78.

35. Koenig S, Probst I, Becker $\mathrm{H}$, et al. Zonal hierarchy of differentiation markers and nestin expression during oval cell mediated rat liver regeneration. Histochem Cell Biol 2006;126:723-34.

36. Roskams T, De Vos R, van Eyken P, et al. Hepatic OV-6 expression in human liver disease and rat experiments: evidence for hepatic progenitor cells in man. J Hepatol 1998;29:455-63.

37. Crosby HA, Hubscher S, Fabris L, et al. Immunolocalization of putative human live progenitor cells in livers from patients with end-stage primary biliary cirrhosis and sclerosing cholangitis using the monoclonal antibody OV-6. Am J Pathol 1998:152:771-9.

38. Haque S, Haruna Y, Saito K, et al. Identification of bipotential progenitor cells in human liver regeneration. Lab Invest 1996;75:699-705.

39. Minervini MI, Demetris AJ, Lee RG, et al. Utilization of hepatocyte-specific antibody in the immunocytochemical evaluation of liver tumors. Mod Pathol 1997;10:686-92.

40. Gleiberman AS, Encinas JM, Mignone JL, et al. Expression of nestin-green fluorescent protein transgene marks oval cells in the adult liver. Dev Dyn 2005;234:413-21.

41. Seki S, Kitada T, Sakaguchi H, et al. Expression of progenitor cell markers in livers with fulminant massive necrosis. Hepatol Res 2003;25:149-57.

42. Bisgaard HC, Parmelee DC, Dunsford HA, et al. Keratin 14 protein in cultured nonparenchymal rat hepatic epithelial cells: characterization of keratin 14 and keratin 19 as antigens for the commonly used mouse monoclonal antibody OV-6. Mol Carcinogen 1993; 7:60-6.

43. Crosby HA, Hubscher SG, Joplin RE, et al. Immunolocalization of OV-6, a putative progenitor cell marker in human fetal and diseased pediatric liver. Hepatology 1998;28:980-5

44. Santoni-Rugiu E, Jelnes $P$, Thorgeirsson SS, et al. Progenitor cells in liver regeneration: molecular responses controlling their activation and expansion. APMIS 2005;113:876-902

45. Schmelzer E, Zhang L, Bruce A, et al. Human hepatic stem cells from fetal and postnatal donors. J Exp Med 2007;204:1973-87.

46. Fox IJ, Chowdhury JR, Kaufman SS, et al. Treatment of the Crigler-Najjar syndrome type I with hepatocyte transplantation. N Engl J Med 1998:338:1422-6.

\section{Take advantage of BMJ Journals' remarkable catalogue of titles with Related Collections}

No busy professional has time to browse through all pertinent journals to find relevant articles, but with Related Collections you no longer have to. Follow the "Related Collections" link from any article and use the "Show Collections from other Journals" to expand your search across all BMJ Journals. Or simply follow the "Browse by topic" link on the home page. By setting up your own collections and receiving email alerts every time an article is added to your chosen area, you can build up your own significant body of knowledge. 